\title{
GROUND-WATER INVESTIGATION AT THE ALLUVIAL FAN OF THE SOUTH FORK EAGLE RIVER, ANCHORAGE, ALASKA - RESULTS OF TEST DRILLING, 1976
}

U. S. Geological Survey

Open-File Report 77-493

Prepared in cooperation with the Municipalify of Anchorage

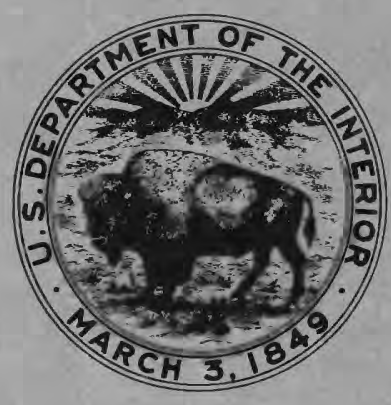




\title{
UNITED STATES \\ DEPARTMENT OF THE INTERIOR \\ GEOLOGICAL SURVEY
}

\begin{abstract}
GROUND-WATER INVESTIGATION AT THE
ALLUVIAL FAN OF THE SOUTH FORK EAGLE RIVER, ANCHORAGE, ALASKA RESULTS OF TEST DRILLING, 1976
\end{abstract}

By
Larry L. Dearborn

Open-File Report 77-493

Anchorage, Alaska

1977 


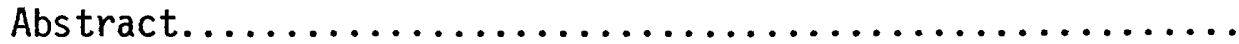

Introduction.

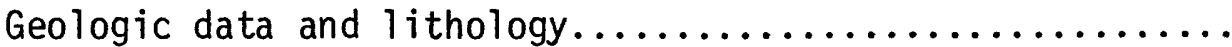

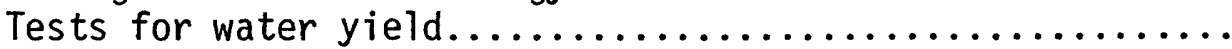

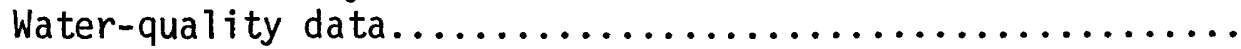

Conclusions.

Selected references.

\section{ILLUSTRATIONS}

Plate 1. Driller's and geophysical logs of well ERTW-76... In pocket

Figure 1. Map showing location of test wells in Eagle River

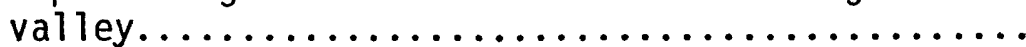

2. Semi-logarithmic plot of water-level drawdown and recovery in well ERTH-76 during aquifer tests on November 4, 1976.

Table 1. Chemical analysis of water from the 343- to 348foot stratum of wel1 ERTW-76.

CONVERSION FACTORS

Multiply English units

feet $(f t)$

gallons per minute (gal/min)

gallons per minute per foot $(\mathrm{gal} / \mathrm{min} / \mathrm{ft})$

inches (in)
By

.3048

.06309

.01923

25.40
To obtain SI units

meters (m)

liters per second (L/S)

liters per second per meter $(\mathrm{L} / \mathrm{s} / \mathrm{m})$

milliliters (mL) 
GROUND-WATER INVESTIGATION AT THE

ALLUVIAL FAN OF THE SOUTH FORK EAGLE RIVER, ANCHORAGE, ALASKA -

RESULTS OF TEST DRILLING, 1976

Larrry L. Dearborn

\begin{abstract}
In late 1976, a ground-water exploration well was drilled to a depth of 487 feet on the South Fork Eagle River fan near the confluence with the mainstream. The well penetrated four sand and gravel strata of low water-yielding capacity and extended $37 \mathrm{ft}$ into metamorphic bedrock. Each water stratum was pumped for several hours, and the best aquifer yield was found to be $1.7 \mathrm{gal} / \mathrm{min} / \mathrm{ft}$ of drawdown. These test results support the conclusion, previously inferred from drilling data at a nearby test hole drilled in 1973, that larger yield, confined aquifers are not present in the subsurface at this locality.
\end{abstract}

\title{
INTRODUCTION
}

This report presents geologic and hydrologic data collected by the U.S. Geological Survey during drilling of an exploratory water well in the Eagle River valley near the confluence of the South Fork Eagle River with the mainstream (fig. 1). The well was drilled by the U.S. Army Corps of Engineers, Alaska District, as part of its Metropolitan Anchorage Urban Study (MAUS). This report is a product of the Geological Survey's participation in a phase of the water-availability and water-supply element of MAUS.

In drilling the test well, the immediate objective of MAUS was to evaluate ground-water supply potential at the selected site. Additionally, it was hoped that aquifer test results at the South Fork fan could be extended to provide an estimate of the potential for developing large, public, ground-water supplies in the Eagle River valley. The role of the Geological Survey was 1 imited to hydrologic-data collection and analys is at the drilling site, with emphasis on analysis of data from pumping tests of the aquifer.

Drilling of the 8-inch-diameter test well, referred to as ERTW-76 (USGS well no. AK-2454) began on September 20, 1976, using a cable-tool drill rig. The drilling site was $195 \mathrm{ft}$ (feet) downvalley from an existing test wel1, ERTH \#2 (USGS well no. AK-2153). We11 ERTH \#2 was drilled as part of an earlier water-availability study conducted for local water utilities (Tryck, Nyman and Hayes, and others, 1973). A 


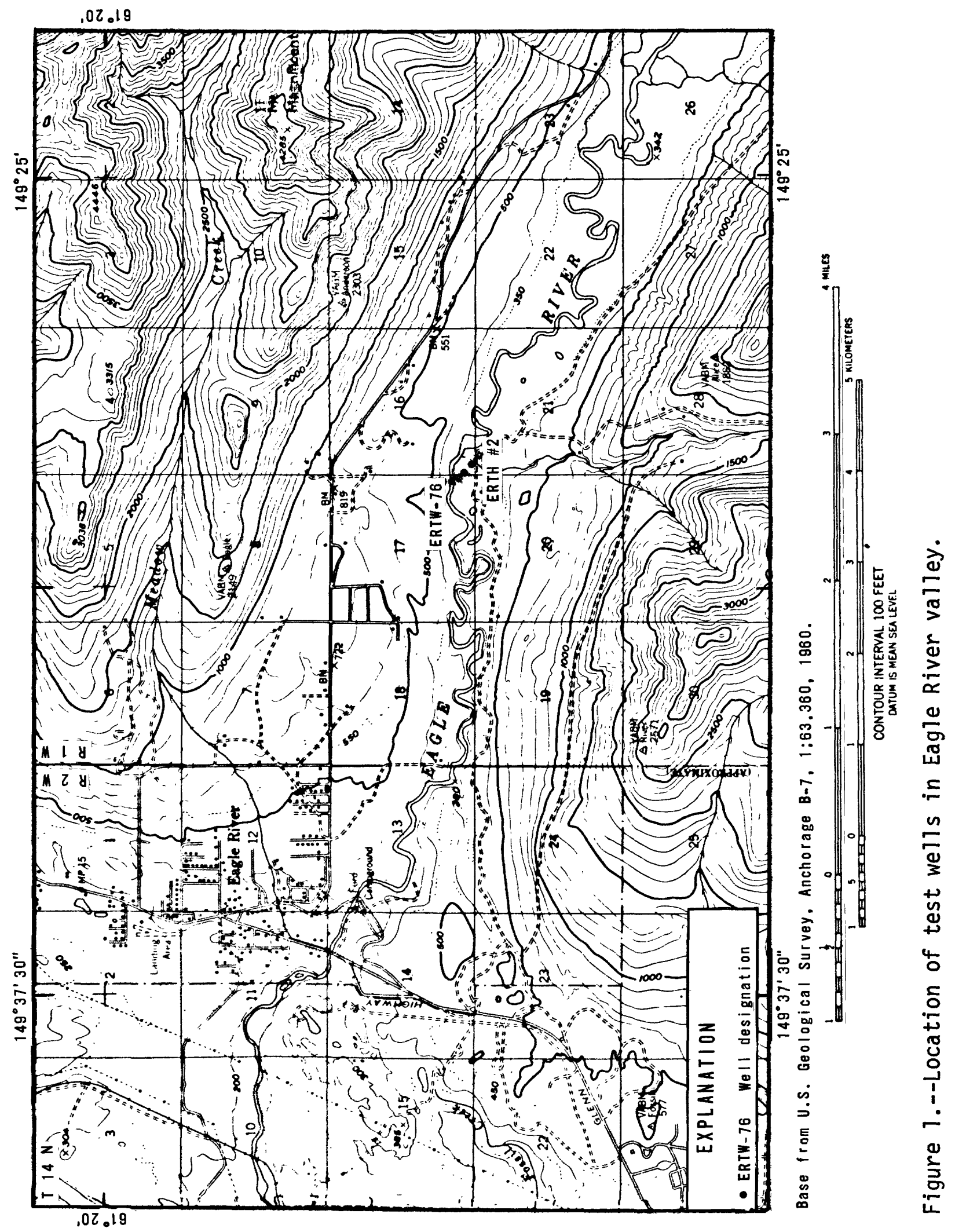


major factor in choosing to drill a test hole at this locality was that previous testing of an apparently promising aquifer, between 320 and 390 $\mathrm{ft}$ below the land surface was inconclusive in defining the potential for public supply (Tryck, Nyman and Hayes, and others, 1973). It was presumed that the proximity of the older well could also prove useful for measuring drawdown during testing of deep aquifers at the new site. Because well-completion difficulties left ERTH \#2 in poor hydraulic connection to the deep water-bearing strata, the Corps of Engineers and USGS agreed that rehabilitation of this well would be undertaken only if an aquifer judged capable of supplying 100-200 gal/min (gallons per minute) was indicated by preliminary pumping tests at the new well.

\section{GEOLOGIC DATA AND LITHOLOGY}

A 1 ithologic log recorded by the driller (Henry Thomas of the Corps of Engineers) and four geophysical well logs recorded by the author are presented in plate 1. Unconsolidated alluvial, glacial, and perhaps estuarine sediments, ranging in particle size from cobbles to clay, were penetrated to a depth of $450 \mathrm{ft}$ below land surface $(-110 \mathrm{ft}$ $M S L$ ). The remainder of the hole (to a final depth of $487 \mathrm{ft}$ ) was drilled into consolidated rock of varying hardness, believed to be bedrock.

The lithologic sequence of ERTW-76 is closely similar to that logged for ERTH \#2 (Tryck, Nyman and Hayes, and others, 1973). As in the earlier well, silt was the dominant geologic material between the shallow alluvium (of the South Fork fan) and deep-lying, till-like material. Several permeable strata, less than $6 \mathrm{ft}$ in thickness and consisting mainly of sand and gravel, were penetrated in the sedimentary material below the $300-\mathrm{ft}$ depth. Water yields from these strata are discussed in the following section.

Hard, seemingly competent rock was recorded at a depth of $450 \mathrm{ft}$, on the basis of drill cuttings, much slower drilling rates, and resistance of the 6-inch liner casing to driving. (The 8-in casing was terminated at the $388 \mathrm{ft}$ depth.) The rock appeared to be greenstone, a typical component of Chugach Mountain bedrock (Clark, 1972). A layer of "softer" rock, which reportedly yielded some silt particles to bailing, was penetrated from 460 to $464 \mathrm{ft}$. Thereafter, the rock became progressiveiy harder (and slower) to drill to the bottom of the hole.

Geophysical logs (p1. 1 in pocket), particularly the natural-gamma log, strongly support the drilling evidence that the top of bedrock was at about $450 \mathrm{ft}$. The gamma-gamma density $10 \mathrm{~g}$ and the neutron-porosity log show typical responses (shift to the right), but an unknown amount of the shifting is due to exiting the steel casing close to the sedimentbedrock contact. The presence of relatively soft material lying between harder rock suggests a narrow fracture filled with silt. 


\section{TESTS FOR WATER YIELDS}

Short pumping tests were conducted as drilling progressed. Flowing artesian conditions were noted during drilling through all of these strata. A summary of pertinent information from tests made on these individual strata follows:

343-348 feet

Approximately $5 \mathrm{ft}$ of no. 40 slot screen was exposed and the section was surged, bailed and pumped for several days, but less than 20 gal of fine material were removed. During much of this time 5 to $10 \mathrm{gal} / \mathrm{min}$ of water flowed over the top of the 8-in-diameter casing that extended 2.7 $\mathrm{ft}$ above ground leve1. A final pumping test was run at a rate of 30 $\mathrm{gal} / \mathrm{min}$ on November 4, 1976, and resulted in $18 \mathrm{ft}$ of drawdown after 90 minutes pumping. The drawdown was increasing very gradually when the test was terminated, and the water contained very few suspended particles. A semi-log plot of the drawdown and recovery data for the test is shown in figure 2 .

A graphic water-level record of ERTH \#2, $195 \mathrm{ft}$ away, showed drawdown in response to pumping at ERTW-76 on October 20. The "sluggishness" (i.e. poor hydraulic connection to aquifer) of ERTH \#2 was demonstrated by a delay in drawdown response of about one hour. Therefore, this well was not monitored during the November 4 test or tests of deeper zones because the data would not represent the true response of the aquifer to pumping stress. The relatively low yield of the new well did not justify redevelopment of ERTH \#2.

\section{3-366 feet}

Three feet of no. 40 slot screen was set in this interval. During brief bailing to develop this water-bearing zone, excessive amounts of fine sand entered the wel1. A centrifugal pump was then operated to produce about $15 \mathrm{gal} / \mathrm{min}$, but drawdown quickly reached the level of the pump intake. The volume of sand pumped indicated that this interval contained too much fine material to be developed effectively.

392-396 feet

A no. 40 slot screen was set, but development failed to improve the yield. Before abandoning this water-bearing zone, a centrifugal pump was installed and pumped at about $15 \mathrm{gal} / \mathrm{min}$. The water level was rapidly drawn down to the pump intake; however, water level recovery was rapid when pumping stopped, and water soon flowed over the casing again. 


\section{$\underline{414-416 \text { feet }}$}

This water-bearing zone appeared promising because of the large size of the gravel and its low silt and clay content. Apparently the uncased hole remained open in this interval. A centrifugal pump was run for two hours at a rate of $35 \mathrm{gal} / \mathrm{min}$. Twenty-four feet of drawdown resulted, and the thin layer was judged not worthy of screening. The static level was more than $4 \mathrm{ft}$ above ground surface, as indicated by artesian flow over the casing. 


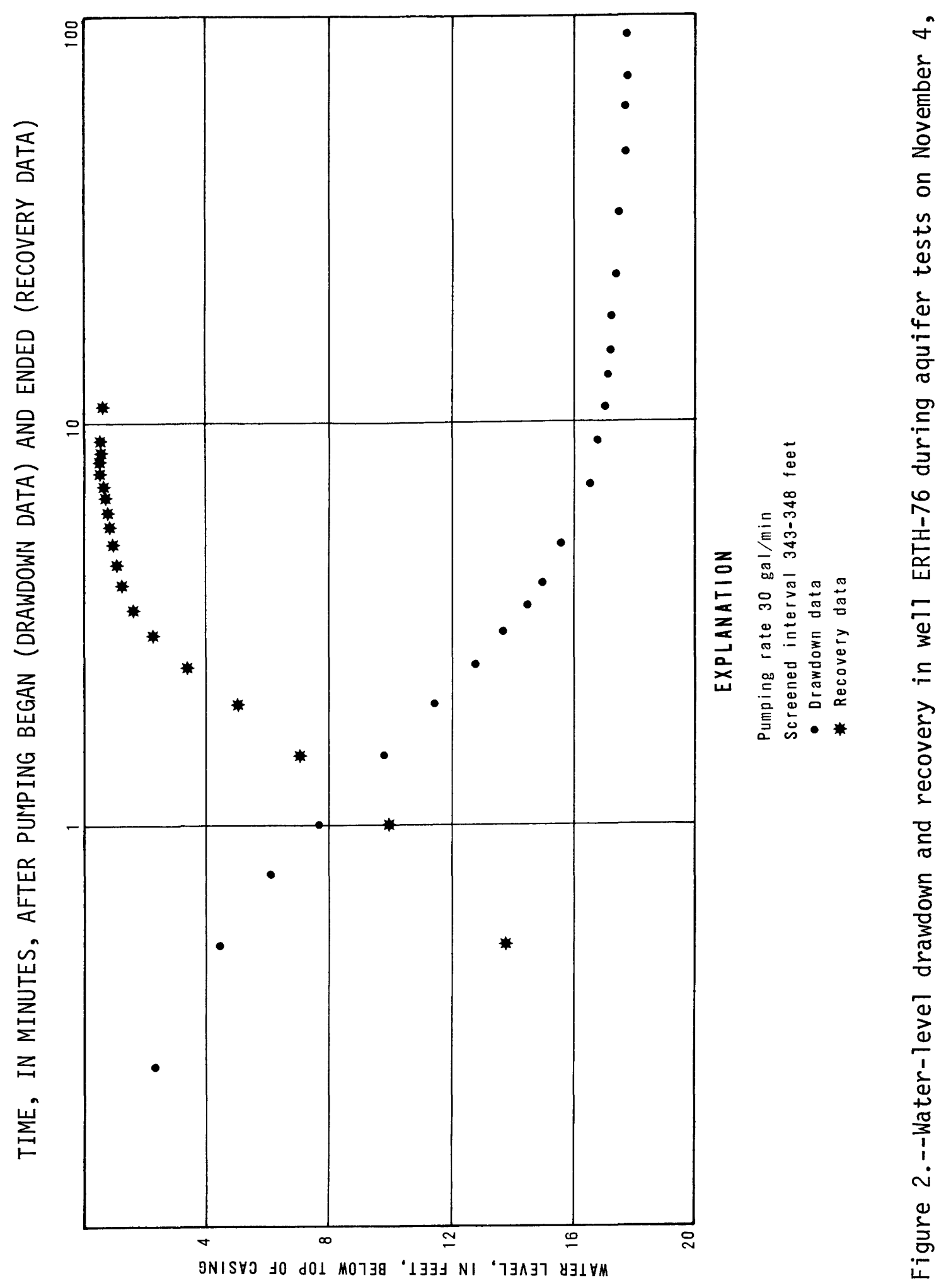




\section{WATER-QUALITY DATA}

An analysis was made by the U.S. Geological Survey of water pumped from the stratum at 343 to 348 feet (see table 1). Field water-quality tests on November 4 showed a specific conductance of 480 umhos per centimeter at $25^{\circ} \mathrm{C}$, pH of about 9 units, and the sampled water had a temperature of $6.8^{\circ} \mathrm{C}$. These values are nearly identical to those obtained luring aquifer development activities two weeks earlier. About 6,300 gallons had been pumped from the well in 3.5 hours prior to sampling. The water had a hydrogen-sulfide odor and an objectionable taste when sampled.

Water samples were collected from the intervals 394 to $399 \mathrm{ft}$ and 414 to $416 \mathrm{ft}$ for field analysis. Conductivities of $230 \mu$ mhos and 600 umhos were determined for these samples, respectively. Both sample bottles contained some sand particles, but no appreciable silt. Upon settling, a reddish (iron) precipitate formed in the sample bottle from the 392- to 396-ft stratum. Also, the driller reported that water pumped from the 414- to 416-ft stratum had a strong sulfide odor and a temperature of $7.5^{\circ} \mathrm{C}$. Although a continuous temperature log was not obtained in ERTW-76, temperature measurements obtained during pumping from strata at various depths indicate a warming gradient with depth similar to that in well ERTH \#2, logged in 1973.

\section{CONCLUSIONS}

Relatively good geologic and hydrologic correlation can be made between ERTW-76 and the previous test we11, ERTH \#2. The data from ERTW-76, Tike those from ERTH \#2, indicated no water-bearing strata capable of sustaining moderate- to large-yield public supply wells (200 gal/min or more). The highest specific capacity attained during testing of aquifers at ERTW-76 was $1.7 \mathrm{gal} / \mathrm{min} / \mathrm{ft}$ of drawdown from the interval 343 to $348 \mathrm{ft}$. Tryck, Nyman and Hayes, and others (1973) reported specific capacities of $4 \mathrm{gal} / \mathrm{min} / \mathrm{ft}$ and $16.6 \mathrm{gal} / \mathrm{min} / \mathrm{ft}$ from brief bailing tests at depths of 344 and $346 \mathrm{ft}$, respectively, in well ERTH \#2. Also, because only 1 foot of relatively permeable aquifer material (at a depth of 48-49 ft) was penetrated in the unconfined system in ERTW-76, the extent of the shallow aquifer tested at well ERTH \#2 is questionable. However, a surprisingly large yield (60 gal/min) was pumped from a 12-ft-deep, open-end casing beside the new test well, which suggests an abundance of very shallow ground water here.

The information gained from the two test wells on the South Fork Eagle River alluvial fan is only a first step in evaluation of the ground-water resource potential of Eagle River valley. Several additional test wells will be required to define the thickness, distribution and hydraulic character of the unconsolidated sediments. The test wells might then be used as control points for surface geophysical surveys, such as electrical resistivity exploration; these data in conjunction 
Table 1.--Chemical analysis of water from the 343- to 348-ft stratum of we11 ERTW-76, November 4, 1976.

\section{Parameter}

Time

Pump period prior to sampling

Flow rate

Specific conductance (at $25^{\circ} \mathrm{C}$ )* $\mathrm{pH}^{*}$

Temperature, water*

Color

Hardness, as $\mathrm{CaCO}_{3}$ ( $\mathrm{Ca}, \mathrm{Mg}$ )

Hardness, noncarbonate

Calcium, dissolved

Magnesium, dissolved

Sodium, dissolved

Potassium, dissolved

Bicarbonate $\left(\mathrm{HCO}_{3}\right)$

Alkalinity (total as $\mathrm{CaCO}_{3}$ )*

Sulfate, dissolved

Chloride, dissolved

Fluoride, dissolved

Silica, dissolved

Dissolved solids, residue at $180^{\circ} \mathrm{C}$

Nitrite plus nitrate, dissolved as $\mathrm{N}$

Phosphorus, dissolved orthophosphate as $P$

Arsenic, dissolved

Iron, dissolved

Manganese, dissolved
Value or

Concentration Unit

$12: 45$

210

30

480

9(approx.)

6.8

6

34

0

10

2.2

95

0.8

188

154

1.8

68

0.4

8.1

284

0.02

0.14

38

110

20 hours

minutes

gal/min umhos/cm

units

${ }^{\circ} \mathrm{C}$

platinumcobalt units

$\mathrm{mg} / \mathrm{L}$

$\mathrm{mg} / \mathrm{L}$

$\mathrm{mg} / \mathrm{L}$

$\mathrm{mg} / \mathrm{L}$

$\mathrm{mg} / \mathrm{L}$

$\mathrm{mg} / \mathrm{L}$

$\mathrm{mg} / \mathrm{L}$

$\mathrm{mg} / \mathrm{L}$

$\mathrm{mg} / \mathrm{L}$

$\mathrm{mg} / \mathrm{L}$

$\mathrm{mg} / \mathrm{L}$

$\mathrm{mg} / \mathrm{L}$

$\mathrm{mg} / \mathrm{L}$

$\mathrm{mg} / \mathrm{L}$

$\mathrm{mg} / \mathrm{L}$

$\mu \mathrm{g} / \mathrm{L}$

$\mu g / L$

$\mu \mathrm{g} / \mathrm{L}$

*determined in field at time of sampling 
with the test-well data would guide selection of the most favorable areas for drilling of possible production wells.

Other investigations might consist of drilling to define the potential for shallow ground-water development in the South Fork fan area, or to define the hydraulic connection of the shallow aquifer with the present Eagle River channel. In the latter case, interpretation of data to determine the degree of ground-water inflow from the river would be difficult and complex, and extension of results to other areas would be tenuous. Any shallow test-drilling program here should include ideally an array of small diameter observation wells around a central pumped wel1.

\section{SELECTED REFERENCES}

Bateman, A.F., Jr., 1948, Reconnaissance report on geology of lower Eagle River Valley, Alaska: U.S. Geol. Survey, 12 p.

Clark, S.H.B., 1972, Reconnaissance bedrock geologic map of the Chugach Mountains near Anchorage, Alaska: U.S. Geol. Survey Misc. Field Studies Map MF-350.

Schmo11, H.R., Dobrovolny, Ernest, and Zenone, Chester, 1971, Generalized geologic map of the Eagle River - Birchwood area, Greater Anchorage Area Borough, Alaska: U.S. Geol. Survey open-file map, 1 sheet.

Tryck, Nyman and Hayes; Dames and Moore; Leeds, Hill and Jewett, 1973, Anchorage Water Sources: prepared for Anchorage Water Utility and Central Alaska Utilities, pub. by City of Anchorage, $307 \mathrm{p}$.

Zenone, Chester, Schmo11, H.R. and Dobrovolny, Ernest, 1974, Geology and ground water for land-use planning in the Eagle River - Chugiak area, Alaska: U.S. Geol. Survey Open-file Report 74-57 (pub. by Greater Anchorage Area Borough), 25 p. 
